The University of Maine

DigitalCommons@UMaine

Earth Science Faculty Scholarship

Earth Sciences

8-16-2007

\title{
Reduction in Northward Incursions of the South Asian Monsoon Since 1400 AD Inferred from a Mt. Everest Ice Core
}

\author{
Susan D. Kaspari \\ Paul Andrew Mayewski \\ University of Maine - Main, paul.mayewski@maine.edu \\ Shichang Kang \\ Sharon B. Sneed \\ Shugui Hou
}

See next page for additional authors

Follow this and additional works at: https://digitalcommons.library.umaine.edu/ers_facpub

Part of the Earth Sciences Commons

\section{Repository Citation}

Kaspari, Susan D.; Mayewski, Paul Andrew; Kang, Shichang; Sneed, Sharon B.; Hou, Shugui; Hooke, Roger; Kreutz, Karl J.; Introne, D.; Handley, M.; Maasch, Kirk A.; Qin, Dahe; and Ren, J., "Reduction in Northward Incursions of the South Asian Monsoon Since $\sim 1400 \mathrm{AD}$ Inferred from a Mt. Everest Ice Core" (2007). Earth Science Faculty Scholarship. 76.

https://digitalcommons.library.umaine.edu/ers_facpub/76

This Article is brought to you for free and open access by DigitalCommons@UMaine. It has been accepted for inclusion in Earth Science Faculty Scholarship by an authorized administrator of DigitalCommons@UMaine. For more information, please contact

um.library.technical.services@maine.edu. 
Authors

Susan D. Kaspari, Paul Andrew Mayewski, Shichang Kang, Sharon B. Sneed, Shugui Hou, Roger Hooke, Karl J. Kreutz, D. Introne, M. Handley, Kirk A. Maasch, Dahe Qin, and J. Ren 


\title{
Reduction in northward incursions of the South Asian monsoon since $\sim 1400$ AD inferred from a Mt. Everest ice core
}

\author{
S. Kaspari, ${ }^{1}$ P. Mayewski, ${ }^{1,2}$ S. Kang, ${ }^{2}$ S. Sneed, ${ }^{1}$ S. Hou, ${ }^{2}$ R. Hooke,${ }^{1}$ K. Kreutz, ${ }^{1}$ \\ D. Introne, ${ }^{1}$ M. Handley, ${ }^{1}$ K. Maasch, ${ }^{1}$ D. Qin, ${ }^{2}$ and J. Ren ${ }^{2}$ \\ Received 19 April 2007; revised 21 June 2007; accepted 19 July 2007; published 16 August 2007.
}

[1] A highly resolved Mt. Everest ice core reveals a decrease in marine and increase in continental air masses related to relatively high summer surface pressure over Mongolia, and reduction in northward incursions of the summer South Asian monsoon since 1400 AD. Previously published proxy records from lower sites south of the Himalayas indicate strengthening of the monsoon since this time. These regional differences are consistent with a southnorth seesaw in convective activity in the Asian monsoon region, and reflect a southward shift in the mean summer position of the monsoon trough since $\sim 1400 \mathrm{AD}$. The change in monsoonal circulation at $1400 \mathrm{AD}$ is synchronous with a reduction in solar irradiance and the onset of the LIA. This demonstrates a hemispheric scale circulation reorganization at this time, and the potential for future large shifts in monsoonal circulation. Citation: Kaspari, S., et al. (2007), Reduction in northward incursions of the South Asian monsoon since $\sim 1400 \mathrm{AD}$ inferred from a Mt. Everest ice core, Geophys. Res. Lett., 34, L16701, doi:10.1029/2007GL030440.

\section{Introduction}

[2] The Asian monsoon is the largest seasonal reversal of wind patterns and precipitation on Earth. Variations in the monsoon can result in severe droughts and torrential rains with serious impacts on roughly $60 \%$ of the global human population living in the region. Modern South Asian monsoon variability is linked with sea surface temperature anomalies [Tschuck et al., 2004], Eurasian snow cover [Sankar-Rao et al., 1996], soil moisture [Douville, 2002], and the El Niño Southern Oscillation [Webster et al., 1998], but understanding of monsoon variability over longer time periods is limited. Proxy records from low elevation regions to the south of the Himalayas indicate a strengthening of the monsoon over the past few centuries [Anderson et al., 2002; von Rod et al., 1999; Wang et al., 2005]. To fully characterize spatial and temporal monsoon variability, highresolution proxy records are also needed from northern regions influenced by the monsoon. Here we use a highresolution calibrated record of the South Asian monsoon from a new Mt. Everest ice core, and examine variations in the monsoon since $1000 \mathrm{AD}$.

\footnotetext{
${ }^{1}$ Climate Change Institute and Department of Earth Sciences, University of Maine, Orono, Maine, USA.

${ }^{2}$ Joint Key Laboratory of Cryosphere and Environment, Lanzhou, China.
}

Copyright 2007 by the American Geophysical Union. 0094-8276/07/2007GL030440

\section{Methods}

[3] In 2002 a $108 \mathrm{~m}$ ice core drilled to bedrock was recovered from the col of the East Rongbuk glacier located on the northeast ridge of Mt. Everest (28.03 N, 86.96 E, $6518 \mathrm{~m}$ ) (Figure 1). The ice core was melted into 3123 samples and analyzed for soluble ions $\left(\mathrm{Na}^{+}, \mathrm{K}^{+}, \mathrm{Mg}^{2+}\right.$, $\left.\mathrm{Ca}^{2+}, \mathrm{Cl}^{-}, \mathrm{NO}_{3}^{-}, \mathrm{SO}_{4}^{2-}\right)$, hydrogen isotopes $(\delta \mathrm{D})$, and $\mathrm{Bi}$. The ice core was annually dated to $1534 \mathrm{AD}$ at a depth of $98 \mathrm{~m}$ using seasonal variations in $\delta \mathrm{D}$ and soluble ions, and the timescale was verified by identifying large volcanic horizons from the first high-resolution measurements of $\mathrm{Bi}$ on an Asian ice core (see auxiliary material ${ }^{1}$ ) (Figure 2). Below $98 \mathrm{~m}$ annual layer counting is not possible due to layer thinning, thus prior to $1534 \mathrm{AD}$ the ice core was dated using a flow model (S. Kaspari et al., Snow accumulation rate on Mt. Everest: Synchroneity with sites across the Tibetan Plateau on 50-100 year timescales, submitted to Journal of Glaciology, 2007).

\section{Results and Discussion}

[4] Climatically, Mt. Everest lies at the boundary of continental air masses associated with the westerlies and marine air masses associated with the summer South Asian monsoon. Variations in the relative contributions of marine versus continental air masses provide information on the strength of the Asian monsoon through time. Empirical orthogonal function (EOF) analysis [Meeker and Mayewski, 2002] conducted on the high-resolution Everest soluble ion and $\delta \mathrm{D}$ time series reveals shared variance among these ice core time series leading to delineation of dominant source regions and transport pathways for ions and $\delta \mathrm{D}$ deposited on Everest. The leading EOF, EOF1, accounts for $41 \%$ of the total variance in the soluble ion and $\delta \mathrm{D}$ time series and explains $55 \%, 61 \%, 74 \%$ and $56 \%$ of the total variance of $\mathrm{Ca}^{2+}, \mathrm{NO}_{3}^{-}, \mathrm{SO}_{4}^{2-}$ and $\mathrm{Mg}^{2+}$, respectively. The high common variance suggests a common source or transport pathway for these ions, with dust from the arid regions of Central Asia being the dominant source [Wake et al., 1993]. In the following analyses we use $\mathrm{Ca}^{2+}$ to represent continental air masses.

[5] EOF2 (24\% of the total variance) accounts for $70 \%$ and $77 \%$ of the total $\mathrm{Na}^{+}$and $\mathrm{Cl}^{-}$, respectively, and is associated with marine air masses from the Bay of Bengal and Arabian Sea that are transported inland during the summer monsoon season [Shrestha et al., 2002]. $\mathrm{Na}^{+}$and $\mathrm{Cl}^{-}$can also have evaporite dust sources [Thompson et al., 2000; Wake et al., 1993] evident by loading of $25 \%$ of the

\footnotetext{
${ }^{1}$ Auxiliary materials are available in the HTML. doi:10.1029/ 2007GL030440.
} 


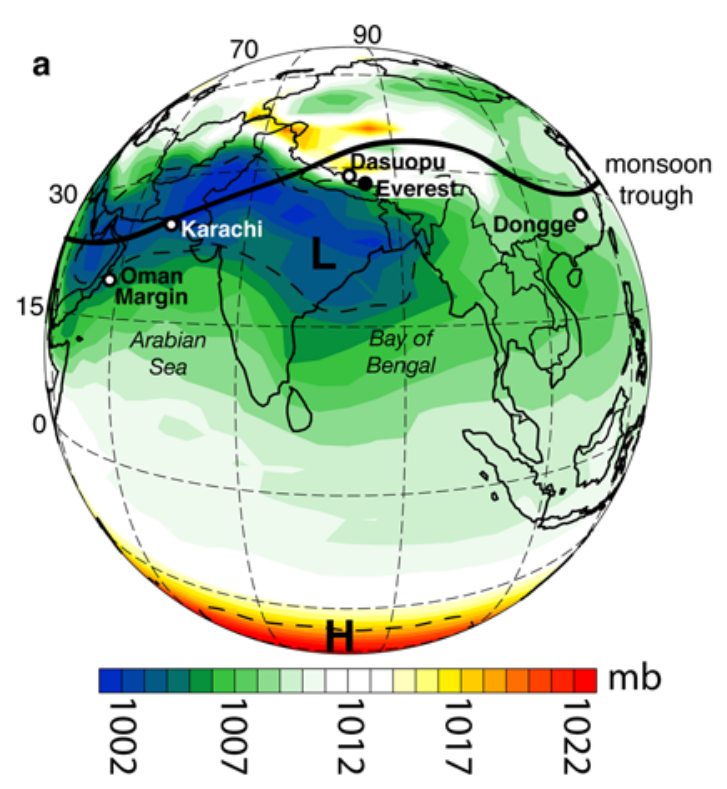

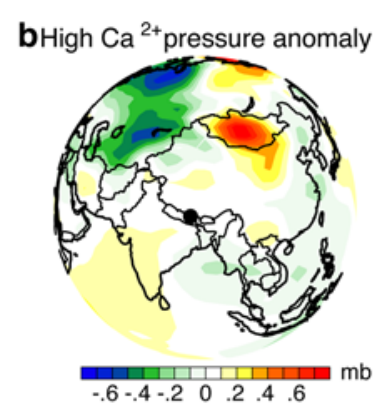

d High $\mathrm{Cl}_{\mathrm{m}}^{*}$ pressure anomaly

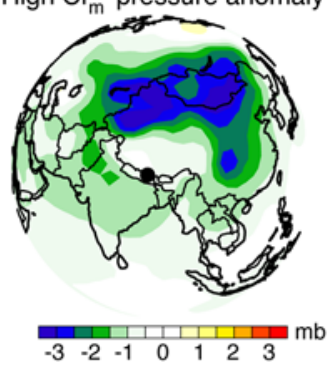

C Low $\mathrm{Ca}^{2+}$ pressure anomaly

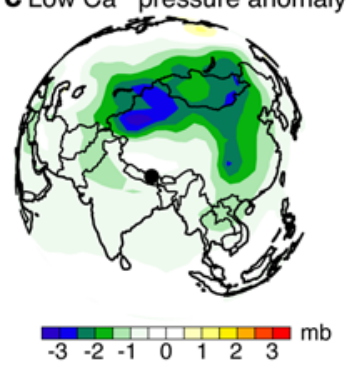

e Low $\mathrm{Cl}_{\mathrm{m}}^{-}$pressure anomaly

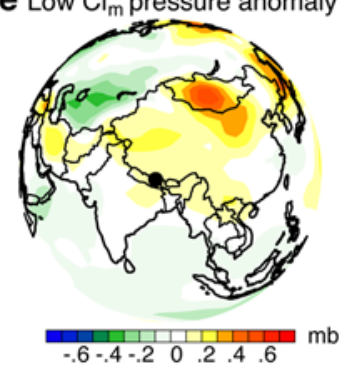

Figure 1. Summer monsoon pressure distribution and anomalies. (a) May-October mean sea level pressure (mb) (19482001) [Kalnay et al., 1996]. $\mathrm{L}=$ Low and $\mathrm{H}=$ High. The bold black line is an idealized representation of the summer position of the monsoon trough. Black and open circles represent the location of Mt. Everest and other proxy records noted in the text, respectively. Surface pressure anomalies (mb) compared to the NCEP mean climatology (1968-1996) for the (b) 13 highest years of mean $\mathrm{Ca}^{2+}$ concentrations (75th percentile); (c) 13 lowest years (25th percentile) of mean $\mathrm{Ca}^{2+}$ concentrations; (d) 13 highest years of mean $\mathrm{Cl}_{\mathrm{m}}^{-}$concentrations; (e) 13 lowest years of mean $\mathrm{Cl}_{\mathrm{m}}^{-}$concentrations.

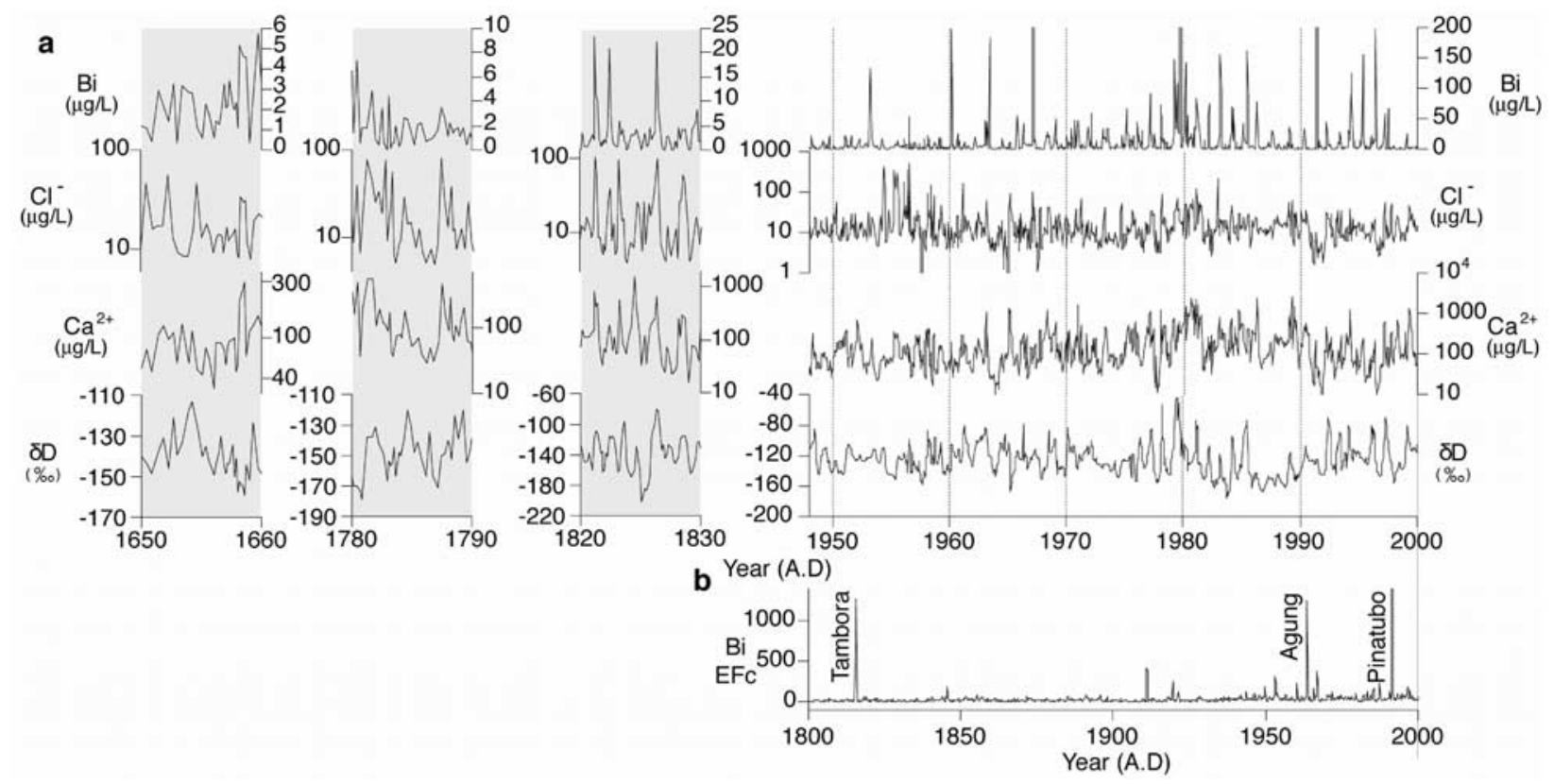

Figure 2. High-resolution multi-parameter dating of the Everest ice core. (a) $\mathrm{Bi}_{1} \mathrm{Cl}^{-}, \mathrm{Ca}^{2+}$, and $\delta \mathrm{D}$ for the periods $1650-$ 1660, 1780-1790, 1820-1830, and 1948-2001 AD (the period of instrumental overlap). The use of multiple parameters improves the dating accuracy of the ice core because of differences in the seasonal input timing for various elements, and eliminates potential errors associated with single parameter dating (e.g. the annual signal is not always preserved in all parameters; double peaks could be mistaken for two years if relying on only one parameter). $\delta \mathrm{D}$ is more negative during the summer monsoon season [Tian et al., 2001, 2003] and dust species $\left(\mathrm{Ca}^{2+}, \mathrm{Mg}^{2+}, \mathrm{NO}_{3}^{-}, \mathrm{SO}_{4}^{2-}\right)$ peak in the late spring to early summer [Wake et al., 1993]. (b) Bi enrichment factor (EFc) from 1800-2000 AD. The large peaks in Bi EFc are related to volcanic eruptions. $\mathrm{Bi} \mathrm{EFc}=\operatorname{median}\left[(\mathrm{Bi} / \mathrm{x})_{\text {ice }} /(\mathrm{Bi} / \mathrm{x})_{\text {upper crust }}\right] ; \mathrm{x}=\mathrm{Sr}, \mathrm{Ca}, \mathrm{La}, \mathrm{Fe}$ and $\mathrm{Al}$. 

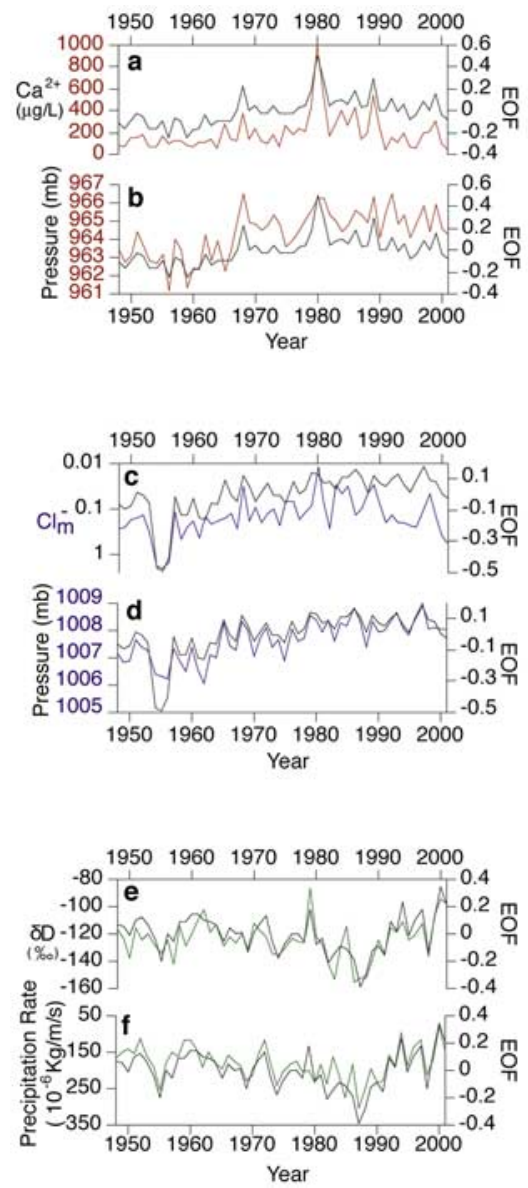

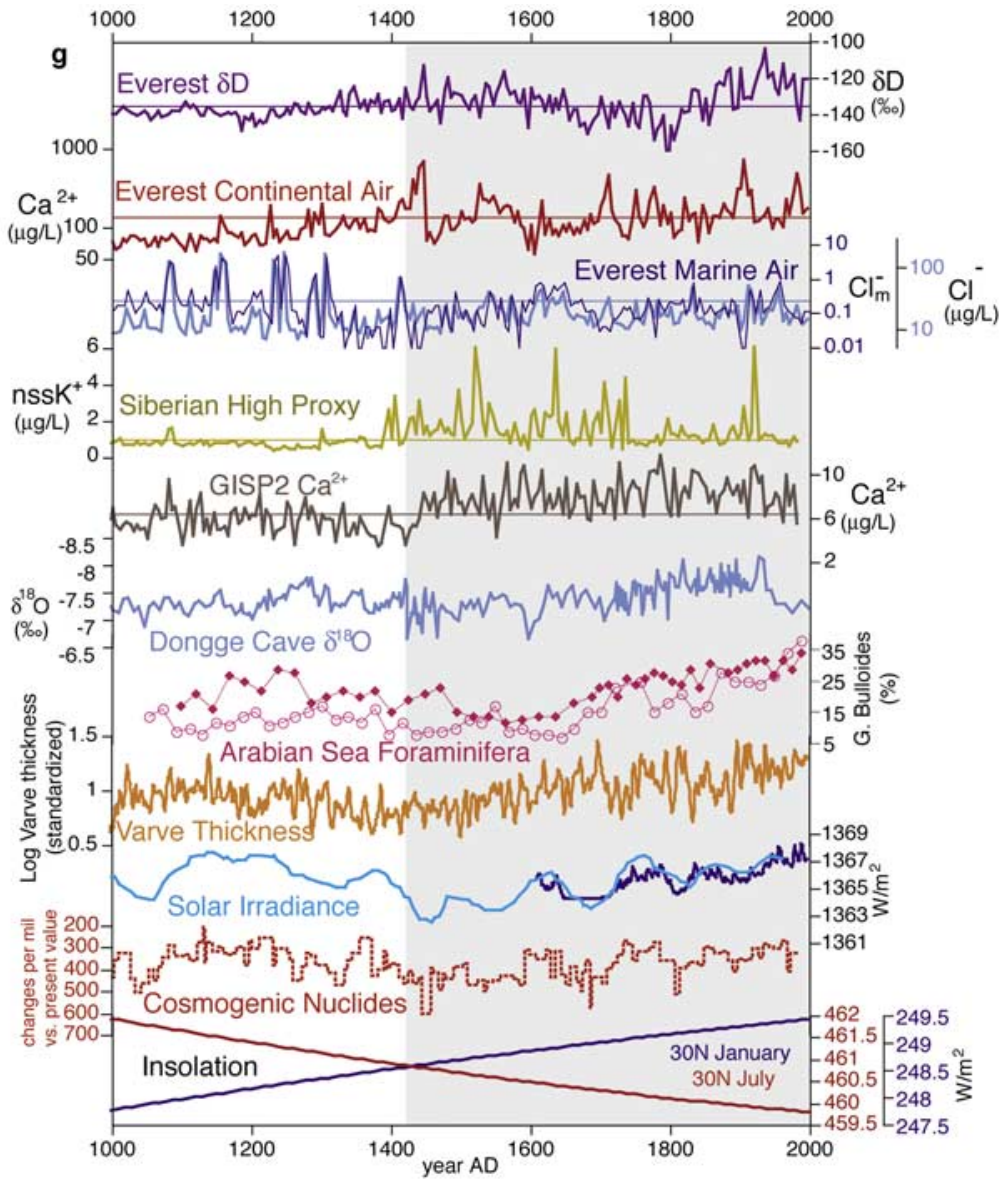

Figure 3. Calibration of the Everest ice core and instrumental records, and proxy data from 1000-2000 AD. (a) Everest mean annual $\mathrm{Ca}^{2+}(\mathrm{ppb})(\mathrm{red})$ and (b) NCEP May-October surface pressure (mb) (red) and their common first EOF (black) representing $75 \%$ of the variance in the two time series; (c) Everest mean annual $\mathrm{Cl}_{\mathrm{m}}^{-}$(blue) and (d) NCEP May-October surface pressure (mb) (blue) and their common first EOF (black) representing 76\% of the variance in the two time series; (e) Everest mean annual $\delta \mathrm{D}(\%)$ (green) and (f) NCEP June-September precipitation rate $\left(10^{-6} \mathrm{~kg} / \mathrm{m} / \mathrm{s}\right.$ ) (green) and their common first EOF (black) representing $71 \%$ of the variance in the two time series. (g) Proxy data. Lines through the data sets are the mean values from 1000-2000 AD, and the shaded region highlights the LIA. The solar irradiance data are from Lean et al. [1995] (dark blue) and Bard et al. [2000] (light blue).

$\mathrm{Na}^{+}$and $18 \%$ of the $\mathrm{Cl}^{-}$on EOF1. $\mathrm{Na}^{+}$and $\mathrm{Cl}^{-}$from evaporites are associated with other evaporite minerals (e.g., gypsum), whereas marine $\mathrm{Na}^{+}$and $\mathrm{Cl}^{-}$are not associated with dust minerals. Thus marine $\mathrm{Na}^{+}$and $\mathrm{Cl}^{-}$sources can be differentiated from evaporite sources by generating a time series for marine $\mathrm{Cl}^{-}\left(\mathrm{Cl}_{\mathrm{m}}^{-}\right)$by: $\mathrm{Cl}^{-}$Normalized $\mathrm{Ca}^{2+}$ Normalized $>0$.

[6] EOF3 (12\% of the total variance) accounts for $89 \%$ of the $\delta \mathrm{D}$, resulting from precipitation events that can occur year round, but are greatest during the summer monsoon season (June-September). Factors that control the stable isotopic composition of precipitation $\left(\delta \mathrm{D}\right.$ and $\left.\delta^{18} \mathrm{O}\right)$ over the Himalayas and Tibetan Plateau include surface air temperature, relative humidity, condensation level, moisture source region, and the amount effect [Tian et al., 2001]. The amount effect refers to the depletion of heavy water isotopes (more negative $\delta \mathrm{D}$ ) during the intense summer monsoon rains, and is the primary seasonal control on $\delta \mathrm{D}$ in the Everest region [Tian et al., 2001, 2003].

[7] Because land heats faster than water, a summer center of low pressure forms over southwest Asia relative to higher pressure over the Indian Ocean (Figure 1a). This difference in pressure drives the summer South Asian monsoon circulation, and affects the large-scale climatology of the region. We assess the influence of atmospheric circulation on the production and transport of chemistry to the Mt. Everest core site by examining associations between pressure from the NCEP/NCAR reanalysis [Kalnay et al., 1996] and the Mt. Everest mean annual glaciochemical time series over the period of overlap 1948-2001.

[8] Everest mean annual $\mathrm{Ca}^{2+}$ is positively correlated with May-October surface pressure [1948-2001: $\mathrm{n}=54$, $\mathrm{r}=.49, \mathrm{p}<.001 ; 1979-2001: \mathrm{n}=23, \mathrm{r}=.52, \mathrm{p}<.01$ (region of highest correlation: $55-57.5 \mathrm{~N}$; 90-105 E); all tests are two-tailed] (Figures 3a and 3b) (see auxiliary material). EOF analysis on the $\mathrm{Ca}^{2+}$ and surface pressure (from the region of highest correlation) time series emphasizes the dominant similarity between the two time series [Meeker and Mayewski, 2002] (Figures 3a and 3b). When May-October pressure in the Mongolian region is relatively high, more dust from continental regions is transported to Mt. Everest, and conversely. An examination of May-October 
surface pressure for years of high (75th percentile) and low (25th percentile) mean $\mathrm{Ca}^{2+}$ concentrations compared to the NCEP mean climatology (1968-1996) further supports this relationship between surface pressure and $\mathrm{Ca}^{2+}$. Pressure is anomalously high (low) over Mongolia in years with high (low) $\mathrm{Ca}^{2+}$ concentrations (Figures $1 \mathrm{~b}$ and $1 \mathrm{c}$ ).

[9] Everest mean annual $\mathrm{Cl}_{\mathrm{m}}^{-}$is negatively correlated with May-October surface pressure [1948-2001: $\mathrm{n}=54, \mathrm{r}=$ $-.51, \mathrm{p}=<.001 ; 1979-2001: \mathrm{n}=23, \mathrm{r}=-.59, \mathrm{p}<.005$ (region of highest correlation: $5-15 \mathrm{~N}, 55-56 \mathrm{E}$ )] (Figures $3 \mathrm{c}$ and $3 \mathrm{~d}$ ), indicating that when surface pressure is lower over southwestern Asia, more marine air masses are transported into the Everest region. An examination of the surface pressure anomalies validates this relationship, with years of high (low) $\mathrm{Cl}_{\mathrm{m}}^{-}$associated with anomalously low (high) pressure (Figures 1d and 1e).

[10] When pressure is relatively high, the ocean-land pressure gradient that is a large driver of summer monsoonal circulation is weakened, resulting in fewer incursions of marine laden monsoonal air masses into the Everest region. Concurrently, the westerly jet stream strengthens and shifts southward over Everest, resulting in increased transport of dust aerosols from south and central Asia to Everest. Conversely, when pressure over southwest Asia is relatively low, the ocean-land pressure gradient is strengthened, and more marine dominated southerly air masses are transported to the Everest region associated with a stronger summer monsoon. The westerly jet weakens and shifts to the north, resulting in less dust deposition at Everest [Webster, 1987]. Spectral analysis further supports the inverse association between the $\mathrm{Ca}^{2+}$ and $\mathrm{Cl}_{\mathrm{m}}^{-}$time series, and reveals a 2-7 year periodicity in the $\mathrm{Cl}_{\mathrm{m}}^{-}$record consistent with a monsoon dominated climate signal (see auxiliary material).

[11] Mean annual $\delta \mathrm{D}$ is inversely correlated with: the annual precipitation rate at nearby Nyalam station $(\mathrm{n}=35$, $\mathrm{r}=-.50, \mathrm{p}<.005(28.18 \mathrm{~N}, 85.97 \mathrm{E}))$; the June-September precipitation rate (the period of peak precipitation) over the Everest region from 1948-2001 (NCEP/NCAR reanalysis; $\mathrm{n}=54, \mathrm{r}=-.42, \mathrm{p}<.005(31 \mathrm{~N}, 92 \mathrm{E}))$ (Figures 3e and 3f); and the June-September precipitation rate over All-India Region 3 [Parthasarathy et al., 1995] (the closest region to Everest) from 1871-2001 $(\mathrm{n}=131, \mathrm{r}=-.21, \mathrm{p}<.01)$. This verifies that the amount effect acts as an important control on seasonal-decadal scale variations in the isotopic composition of Everest precipitation. More specifically, precipitation increases during periods of more intense convective activity, resulting in more negative $\delta \mathrm{D}$. Variations in convective activity (i.e., amount effect) and moisture source region related to changes in atmospheric circulation are the dominant controls on the isotopic composition of precipitation in this region (see auxiliary material).

[12] Using the $\mathrm{Ca}^{2+}$ and $\mathrm{Cl}_{\mathrm{m}}^{-}$-surface pressure and $\delta$ D-precipitation rate calibrations from 1948-2001 enables us to reconstruct the pressure distribution and atmospheric circulation over the eastern Himalaya prior to the instrumental record. The most notable feature of the 1000 year record is a decrease in large incursions of marine air masses $\left(\mathrm{Cl}_{\mathrm{m}}^{-}\right)$since $\sim 1330 \mathrm{AD}$ and an overall increase in incursions of continental air masses $\left(\mathrm{Ca}^{2+}\right)$ since $\sim 1420 \mathrm{AD}$, indicating a weakening summer monsoon influence in the Everest region since $\sim 1400$ AD (Figure $3 \mathrm{~g}$ ). These shifts are associated with relatively higher surface pressure over the continental interior during the summer monsoon season, and consequent reduction in the northward extent of the summer moisture-bearing monsoon. This is consistent with previous research that demonstrated an increase in pressure over Siberia as of 1400 AD [Meeker and Mayewski, 2002] (Figure 3g).

[13] Synchronous with the shifts in $\mathrm{Ca}^{2+}$ and $\mathrm{Cl}_{\mathrm{m}}^{-}, \delta \mathrm{D}$ is less negative post $1400 \mathrm{AD}$. This shift is inferred to be due to (1) a reduction in convective activity, resulting in less isotopic fractionation (less negative $\delta \mathrm{D}$ ) and a decrease in precipitation, and (2) a relative increase (decrease) in continental (marine) precipitation at this time. A decrease in Everest ice core calculated annual snow accumulation from 1534 to $1950 \mathrm{AD}$ supports the first finding (auxiliary material Figure S1). With regard to the second, the isotopic composition of precipitation increases north of the Himalayas and with increasing latitude across the Tibetan Plateau [Tian et al., 2001]. Thus, a relatively greater contribution of continental precipitation contributes to the less negative $\delta \mathrm{D}$ values post $1400 \mathrm{AD}$. This is consistent with the relative increase in continental air masses since $\sim 1400 \mathrm{AD}$ evident from the $\mathrm{Ca}^{2+}$ and $\mathrm{Cl}_{\mathrm{m}}^{-}$time series. Both reduced convective activity and a decrease in the relative contribution of monsoonal precipitation are consistent with a weakening monsoon influence in the Everest region since $1400 \mathrm{AD}$ (see auxiliary material).

[14] Interannual variations in the northward displacement of the monsoon trough during summer are related to the strength of the low-pressure cell over southwest Asia (Figure 1a). (Herein the term 'monsoon trough' refers to the region of trade wind convergence over South Asia, equivalent to the Intertropical Convergence Zone (ITCZ) when located over the ocean.) During summers when pressure is relatively low, the mean position of the monsoon trough is farther north, enabling more marine air to penetrate into the Everest region. Thus, variations in the relative contributions through time of continental versus marine air masses from the Everest ice core provides a proxy for the surface pressure distribution, strength of the summer monsoon, and mean summer position of the monsoon trough.

[15] Because the summer Asian monsoon is driven by components of the climate system from both southerly low elevation and northerly high elevation regions, highresolution climate records from both the north and south are essential for assessing variations in the summer monsoon through time. In contrast to the weakening of the South Asian monsoon since $\sim 1400$ AD evident from the Everest ice core, low elevation records from south of the Himalayas suggest a strengthening of the monsoon. Notably a reconstruction of monsoon winds from Globigerina bulloides from Arabian Sea box cores near the Oman Margin indicates increasing monsoon winds since $\sim 1600 \mathrm{AD}$ [Anderson et al., 2002]; varved marine sediments from near Karachi, Pakistan show increasing varve thickness since $\sim 1400$ AD suggesting increasing precipitation [von Rod et al., 1999]; and more negative $\delta^{18} \mathrm{O}$ of a stalagmite from Dongge Cave in Southern China indicates increasing precipitation [Wang et al., 2005] since $\sim 1450 \mathrm{AD}$ (Figures 1 and $3 \mathrm{~g}$ ).

[16] These south-north differences are consistent with observational studies indicating that the summer Asian monsoon trough favors two locations, one over the continent and the other over the ocean. An active period of 
convergence in one of these locations coincides with a weak period in the other [Waliser and Gautier, 1993; Chandrasekar and Kitoh, 1998], resulting in the southnorth differences in monsoon strength evident from the proxy records. The change in monsoon strength at $\sim 1400 \mathrm{AD}$ is likely caused by a southward shift in the overall position of the monsoon trough, or a change in the duration and location of active and break monsoonal periods. The change in monsoon strength since $\sim 1400$ AD at Dongge Cave, the easternmost site, is not as well defined as at the other sites. Thus, the southward shift in the summer monsoon trough at $\sim 1400$ AD may have been greater in western regions of monsoon influence.

[17] A change in insolation (at $30^{\circ} \mathrm{N}$ ) from 1000-2000 AD is consistent with a southward shift in the mean summer position of the monsoon trough. January insolation has increased $\left(1.7 \mathrm{~W} / \mathrm{m}^{2}\right)$, whereas July insolation decreased $\left(2.1 \mathrm{~W} / \mathrm{m}^{2}\right)$ over the period 1000-2000 AD [Berger, 1978] (Figure $3 \mathrm{~g}$ ). This reduction in the seasonality of insolation reduces differential seasonal heating, and likely contributed to a weakening of the pressure differences that promoted the northward displacement of the monsoon trough during summer. This reasoning does not explain the relatively abrupt change in monsoonal circulation at $\sim 1400$ AD evident from the proxy records, but an increase in cosmogenic nuclide production associated with a decrease in solar irradiance from the late 1300 s to $1450 \mathrm{AD}$ may [Bard et al., 2000] (Figure 3g).

[18] Previous research suggests that changes in monsoon strength are associated with solar output [Neff et al., 2001; Fleitmann et al., 2003; Gupta et al., 2005; Wang et al., 2005] and that solar activity can alter the south-north seesaw of convective activity in the Indian region [Chandrasekar and Kitoh, 1998; Kodera, 2004]. During periods of high solar activity, increased equatorial convection results in increased monsoon strength in southern regions of monsoon influence [Neff et al., 2001; Fleitmann et al., 2003; Gupta et al., 2005]. Conversely, the decrease in solar irradiance at $\sim 1400$ AD coincides with reduced monsoon strength at all four proxy record sites. Post $\sim 1400$ AD the monsoon intensifies in southern regions, but remains relatively weak in the Everest region. These south-north differences are consistent with the previously mentioned seesaw pattern in monsoon strength. The mechanism for how variations in solar irradiance affect the monsoon is not well understood; solar irradiance variations are small, and are not likely to have directly caused large differences in sensible heating of the Tibetan Plateau [Neff et al., 2001]. Variations in solar variability may lead to changes in atmospheric or oceanic circulation, amplifying the effect of changes in solar irradiance [Mayewski et al., 2006].

[19] Other climate records indicate a shift in the climate system at $\sim 1400 \mathrm{AD}$ associated with the onset of the Little Ice Age (LIA): GISP2 $\mathrm{Ca}^{2+}$ increases indicating intensified atmospheric circulation [O'Brien et al., 1995]; GISP2 nssK $^{+}$suggests higher pressure over Siberia [Meeker and Mayewski, 2002] (Figure 3g); and temperature in the northern hemisphere [Mann and Jones, 2003] and China [Yang et al., 2002] decreased (see auxiliary material). Thus, changes in monsoon strength at $\sim 1400$ AD may be associated with a reduction in solar irradiance and the onset of the LIA. It is notable that cooler conditions that in part characterize the LIA have returned to warmer conditions since $\sim 1850 \mathrm{AD}$, yet intensified atmospheric circulation persists, as does the change in monsoonal circulation since $\sim 1400$ AD. This suggests that LIA atmospheric conditions continue at present [Mayewski et al., 2006; O'Brien et al., 1995] despite the warming over the past 150 years that is frequently regarded as the end of the LIA.

[20] Acknowledgments. This research was funded by NSF ATM 0139491, NOAA NA05OAR4311109, the Natural Science Foundation of China $(90411003,40401054)$ and the Chinese Academy of Sciences ("Talents Project" and the 3rd Innovation Programs: KZCX3-SW-339/ 344). We thank Zhang Yongliang, the ice core driller, and the 2002 expedition staff for their excellent work in the field.

\section{References}

Anderson, D. M., J. T. Overpeck, and A. K. Gupta (2002), Increase in the Asian Southwest monsoon during the past four centuries, Science, 297, 596-599.

Bard, E., G. Raisbeck, F. Yiou, and J. Jouzel (2000), Solar irradiance during the last 1200 years based on cosmogenic nuclides, Tellus, Ser. B, 52(3), 985-992.

Berger, A. (1978), Long-term variations of daily insolation and Quaternary climatic changes, J. Atmos. Sci., 35(12), 2362-2367.

Chandrasekar, A., and A. Kitoh (1998), Impact of localized sea surface temperature anomalies over the equatorial Indian ocean on the Indian summer monsoon, J. Meteorol. Soc. Jpn., 76(6), 841-853.

Douville, H. (2002), Influence of soil moisture on the Asian and African Monsoons. Part II: Interannual variability, J. Clim., 15, 701-720.

Fleitmann, D., S. J. Burns, M. Mudelsee, U. Neff, J. Kramers, A. Mangini, and A. Matter (2003), Holocene forcing of the Indian monsoon recorded in a stalagmite from Southern Oman, Science, 300, 1737-1739.

Gupta, A. K., M. Das, and D. M. Anderson (2005), Solar influence on the Indian summer monsoon during the Holocene, Geophys. Res. Lett., 32, L17703, doi:10.1029/2005GL022685.

Kalnay, E., et al. (1996), The NCEP/NCAR reanalysis 40-year Project, Bull. Am. Meteorol. Soc., 77, 437-471.

Kodera, K. (2004), Solar influence on the Indian Ocean Monsoon through dynamical processes, Geophys. Res. Lett., 31, L24209, doi:10.1029/ 2004GL020928.

Lean, J., J. Beer, and R. Bradley (1995), Reconstruction of solar irradiance since 1610: Implications for climate change, Geophys. Res. Lett., 22(23), 3195-3198.

Mann, M. E., and P. D. Jones (2003), Global surface temperatures over the past two millennia, Geophys. Res. Lett., 30(15), 1820, doi:10.1029/ 2003GL017814.

Mayewski, P. A., et al. (2006), Solar forcing of the polar atmosphere, Ann. Glaciol., 41(1), 147-154.

Meeker, L. D., and P. A. Mayewski (2002), A 1400-year high-resolution record of atmospheric circulation over the North Atlantic and Asia, Holocene, 12(3), 257-266.

Neff, U., S. J. Burns, A. Mangini, M. Mudelsee, D. Fleitmann, and A. Matter (2001), Strong coherence between solar variability and the monsoon in Oman between 9 and 6 kyr ago, Nature, 411(6835), 290-293.

O'Brien, S. R., P. A. Mayewski, L. D. Meeker, D. A. Meese, M. S. Twickler, and S. I. Whitlow (1995), Complexity of Holocene climate as reconstructed from a Greenland ice core, Science, 270, 1962-1964.

Parthasarathy, B., A. A. Munot, and D. R. Kothawale (1995), Monthly and seasonal rainfall series for All-India homogenous regions and meteorological subdivisions: 1871-1994, Res. Rep. RR-065, Ind. Inst. of Trop. Meteorol., Maharashtra, India.

Sankar-Rao, M., K. Lau, and S. Yang (1996), On the relationship between Eurasian snow cover and the Asian summer monsoon, Int. J. Climatol., $16,605-616$

Shrestha, A. B., C. P. Wake, J. Dibb, and S. I. Whitlow (2002), Aerosol and precipitation chemistry at a remote Himalayan site in Nepal, Aerosol Sci. Technol., 36, 441-456.

Thompson, L. G., T. Yao, E. Mosley-Thompson, M. Davis, B. Henderson, and P. N. Lin (2000), A high-resolution millennial record of the South Asian Monsoon from Himalayan ice cores, Science, 289, 1916-1919.

Tian, L., V. Masson-Delmotte, M. Stievenard, T. Yao, and J. Jouzel (2001), Tibetan Plateau summer monsoon northward extent revealed by measurements of water stable isotopes, J. Geophys. Res., 106, 28,081-28,088.

Tian, L., T. Yao, P. F. Schuster, J. W. C. White, K. Ichiyanagi, E. Pendall, J. Pu, and W. Yu (2003), Oxygen-18 concentrations in recent precipitation and ice cores on the Tibetan Plateau, J. Geophys. Res., 108(D9), 4293, doi:10.1029/2002JD002173. 
Tschuck, P., F. Chauvin, B. Dong, and K. Arpe (2004), Impact of seasurface temperature anomalies in the equatorial Indian Ocean and western Pacific on the Asian summer monsoon in three general circulation models, Int. J. Climatol., 24, 181-191.

von Rod, U., M. Schaaf, K. H. Michels, H. Schulz, W. H. Berger, and F. Sirocko (1999), A 5000-yr record of climate change in varved sediments from the oxygen minimum zone off Pakistan, Northeastern Arabian Sea, Quat. Res, 51, 39-53.

Wake, C. P., P. A. Mayewski, X. Zichu, W. Ping, and L. Zhongqin (1993), Regional distribution of monsoon and dust signals in Asian glaciers, Geophys. Res. Lett., $20(14), 1411-1414$.

Waliser, D. E., and C. Gautier (1993), A satellite-derived climatology of the ITCZ, J. Clim., 6, 2162-2174.

Wang, Y., C. Hai, R. L. Edwards, Y. He, X. Kong, Z. Zn, J. Wu, M. Kelly, C. Dykoski, and Y. Li (2005), The Holocene Asian monsoon: Links to solar changes and North Atlantic climate, Science, 308, 854-857.
Webster, P. J. (1987), The variable and interactive monsoon, in Monsoons, edited by J. S. Fein and P. L. Stephens, 632 pp., John Wiley, Hoboken, N. J.

Webster, P. J., T. Palmer, M. Yanai, R. Tomas, V. Magana, J. Shukla, and A. Yasunari (1998), Monsoons: Processes, predictability, and the prospects for prediction, J. Geophys. Res., 103, 14,451-14,510.

Yang, B., A. Braeuning, K. Johnson, and Y. Shi (2002), General characteristics of temperature variation in China during the last two millennia, Geophys. Res. Lett., 29(9), 1324, doi:10.1029/2001GL014485.

M. Handley, R. Hooke, D. Introne, S. Kaspari, K. Kreutz, K. Maasch, P. Mayewski, and S. Sneed, Climate Change Institute and Department of Earth Sciences, University of Maine, Orono ME 04469, USA. (susan. kaspari@maine.edu)

S. Hou, S. Kang, D. Qin, and J. Ren, Joint Key Laboratory of Cryosphere and Environment, Lanzhou 730000, China. 